\title{
DIMENSI KUALITAS PELAYANAN SEBAGAI UPAYA PENINGKATAN KEPUASAN PELANGGAN (Studi Pada Pelanggan Hotel X Semarang)
}

\author{
Fera Kurniasari ${ }^{1}$, Eviatiwi Kusumaningtyas Sugiyanto ${ }^{2}$ \\ Universitas Semarang ${ }^{1,2}$
}

Email korespondensi : eviatiwisugiyanto@usm.ac.id ${ }^{2}$

Received: 26 Sept 2020 Reviewed: 27 Sept 2020 Accepted: 1 Oct $2020 \quad$ Published:30 Oct 2020

\begin{abstract}
The problem in this study is the number of customer complaints at one of the Online Travel Agents (OTA) who stay at Hotel X Semarang which is allegedly caused by a condition between customer expectations and service quality. This study aims to analyze evidence of the physical effect (tangible), reliability, responsiveness, assurance, and empathy on customer satisfaction at Hotel X Semarang. The population in this study were customers at Hotel X Semarang with an unknown number. While the sampling technique used was purposive sampling with 96 respondents. From multiple linear regression analysis, the results shows that the variables of physical evidence (tangible), reliability, responsiveness, assurance and empathy have a positive and significant effect on customer satisfaction at Hotel X Semarang.
\end{abstract}

Keywords: Service Quality, Customer Satisfaction

\begin{abstract}
ABSTRAK
Permasalahan dalam penelitian ini adalah banyaknya keluhan pelanggan pada salah satu Agen Perjalanan Online (OTA) yang menginap di Hotel X Semarang yang diduga disebabkan oleh kondisi antara harapan pelanggan dengan kualitas layanan. Penelitian ini bertujuan untuk menganalisis bukti pengaruh fisik (tangible), reliabilitas, daya tanggap, jaminan, dan empati terhadap kepuasan pelanggan di Hotel X Semarang. Populasi dalam penelitian ini adalah pelanggan Hotel X Semarang dengan jumlah yang tidak diketahui. Sedangkan teknik pengambilan sampel yang digunakan adalah purposive sampling dengan 96 responden. Dari analisis regresi linier berganda, hasil penelitian menunjukkan bahwa variabel bukti fisik, keandalan, daya tanggap, jaminan, dan empati berpengaruh positif dan signifikan terhadap kepuasan pelanggan di Hotel X Semarang.
\end{abstract}

Kata kunci: Kualitas Pelayanan, Kepuasan Konsumen

\section{A. PENDAHULUAN}

Kepariwisataan dan perhotelan memiliki hubungan yang sangat erat. Hotel merupakan sarana pokok kepariwisataan yang berarti hidup dan kehidupannya banyak tergantung oleh jumlah wisatawan yang datang. Menurut Sulastiyono (2011), hotel adalah suatu perusahaan yang dikelola oleh pemiliknya dengan menyediakan pelayanan makanan, minuman, dan 
fasilitas kamar untuk tidur kepada orang-orang yang melakukan perjalanan dan mampu membayar dengan jumlah yang wajar sesuai dengan pelayanan yang diterima tanpa adanya perjanjian khusus. Saat ini hotel bukan hanya untuk berakhir pekan melainkan digunakan untuk acara pernikahan, rapat perusahaan, dan launching product. Jika sebelumnya kamar atau penginapan menjadi produk atau jasa utama kebutuhan wisatawan, saat ini berkembang menitikberatkan pada pentingnya kualitas layanan yang diinginkan oleh pelanggan yang tidak hanya sebatas kamar untuk menginap.

Semakin besarnya persaingan, pihak hotel dituntut untuk lebih meningkatkan kualitas pelayanan untuk meningkatkan kepuasan pelanggannya. Menurut Hasan (2009), syarat yang harus dipenuhi oleh sebuah perusahaan agar dapat sukses dalam persaingan adalah berusaha mencapai tujuan untuk menciptakan dan mempertahankan pelanggan. Laziami (2015) menyatakan bahwa salah satu strategi untuk memenangkan persaingan di era globalisasi dalam mempertahankan pelanggan saat ini adalah dengan mempertahankan atau meningkatkan "customer satisfaction" (kepuasan pelanggan). Kepuasan pelanggan merupakan salah satu kunci sukses keberhasilan suatu usaha. Dengan memuaskan konsumen, organisasi dapat menaikkan tingkat keuntungannya dan mendapatkan pangsa pasar yang lebih luas. Kepuasan pelanggan muncul karena harapan yang ada pada pelanggan terpenuhi dari kemampuan produk yang dikonsumsinya. Kepuasan konsumen merupakan tanda bahwa keinginan dan kebutuhannya terpenuhi secara baik dari produk yang dikonsumsinya (Tjiptono, 2012). Sedangkan menurut Kotler dan Keller (2012) hasil perbandingan antara kinerja nyata produk dan ekpektasi dari konsumen akan memunculkan kepuasan. Jika ekspektasi terpenuhi atau bahkan kinerja lebih dari ekspektasi maka kepuasan akan semakin tinggi, sebaliknya jika kinerja produk gagal memenuhi harapan/ekspektasi, maka kepuasan konsumen akan merasa tidak puas.

Banyak faktor yang menentukan keberhasilan jangka panjang atau keberlangsungan suatu organisasi (Ahmed et.al, 2010). Kepuasan pelanggan menjadi salah satu faktor keberhasilan organisasi, perusahaan harus memuaskan pelanggannya dengan menyediakan layanan yang berkualitas. Pelanggan cenderung akan membandingkan produk/layanan dari perusahaan satu dengan yang lain, jika dia merasa tidak puas dengan produk atau layanan suatu perusahaan maka mereka akan lebih mudah beralih ke produk atau layanan perusahaan lainnya. Hal tersebut juga berlaku pada salah satu hotel berbintang di Semarang yaitu Hotel $X$. Hotel X merupakan hotel bintang 2 yang ada di Semarang. Hotel ini memiliki jumlah kamar sebanyak 46 kamar, fasilitas yang ditawarkan yaitu $A C$, telepon, televisi, restoran, 
meeting room, hall, dan room service. Hotel bintang 2 ini memiliki banyak pesaing yang tersebar di Semarang. Hotel X hendaknya dapat meningkatkan kualitas pelayanan yang dapat memberikan kepuasan yang lebih terhadap wisatawan yang menginap. Hal tersebut dilakukan karena banyaknya keluhan pelanggan disalah satu Online Travel Agent (OTA) yang menginap di Hotel $\mathrm{X}$ yang diduga diakibatkan karena adanya kesenjangan antara harapan pelanggan dan kualitas dari pelayanan. Tabel 1 menampilkan jenis dan jumlah keluhan pelanggan yang menginap di Hotel X selama tahun 2016-2019.

Tabel 1 menunjukkan bahwa jumlah keluhan dari tahun 2016 hingga 2019 cenderung meningkat dengan angka yang bervariasi pada setiap keluhan. Dalam 4 tahun terakhir angka keluhan pada kebersihan kamar cenderung meningkat, keluhan pada fasilitas kamar tidak stabil, keluhan pada menu makanan dan minuman tidak stabil, keluhan pada pelayanan cenderung meningkat, dan keluhan pada keterampilan karyawan dalam bertugas cenderung meningkat.

Tabel 1. Jenis dan Jumlah Keluhan Pelanggan di Hotel X Tahun 2016 - 2019

\begin{tabular}{|c|l|c|c|c|c|}
\hline \multirow{2}{*}{ No. } & \multirow{2}{*}{ Jenis Keluhan Pelanggan } & \multicolumn{5}{|c|}{ Jumlah Keluhan (Orang) } \\
\cline { 3 - 6 } & $\mathbf{2 0 1 6}$ & $\mathbf{2 0 1 7}$ & $\mathbf{2 0 1 8}$ & $\mathbf{2 0 1 9}$ \\
\hline 1 & Kebersihan kamar hotel & 6 & 17 & 17 & 18 \\
\hline 2 & Fasilitas kamar hotel & 21 & 13 & 21 & 22 \\
\hline 3 & $\begin{array}{l}\text { Menu makanan dan } \\
\text { minuman }\end{array}$ & 11 & 12 & 7 & 8 \\
\hline 4 & Pelayanan & 3 & 7 & 12 & 12 \\
\hline 5 & $\begin{array}{l}\text { Keterampilan dalam } \\
\text { bertugas }\end{array}$ & 1 & 3 & 6 & 6 \\
\hline \multicolumn{2}{|l|}{ TOTAL } & 21 & 52 & 63 & 66 \\
\hline
\end{tabular}

Sumber : OTA Hotel X, 2016-2019

Berita negatif dari pelanggan yang merasa tidak puas terhadap suatu produk atau layanan akan menjadi word of mouth yang dapat menyulitkan perusahaan. Berita negatif tersebut jelas sekali akan berdampak negatif pula pada citra perusahaan, dan menyebabkan pelanggan pindah ke produk pesaing. Kepuasan pelanggan sangat penting untuk mempertahankan pelanggan, karena untuk mendapatkan pelanggan baru memerlukan biaya 4 (empat) kali lebih besar daripada biaya mempertahankan pelanggan (Gocek, 2007). Sisi positif dari komplain pelanggan adalah perusahaan dapat menangkap peluang perbaikan dan peningkatan pelayanan sesuai keinginan dan harapan pelanggan. 
Untuk memenuhi keinginan pelanggan agar mereka merasa puas, hal yang dapat dilakukan suatu perusahaan untuk menunjukkan keunggulan adalah melalui peningkatan kualitas jasa. Tjiptono \& Chandra (2011) menyebutkan ada 5 (lima) dimensi dari kualitas pelayanan jasa yaitu bukti fisik (tangibles), keandalan (realibility), daya tanggap (responsiveness), jaminan (assurance), dan empati (empathy), dimensi tersebut sangat berpengaruh terhadap kepuasan pelanggan. Kelima dimensi ini yang akan digunakan untuk mengukur tingkat kualitas layanan di suatu perusahaan. Kualitas pelayanan adalah sesuatu yang harus dikerjakan oleh penyedia jasa dengan baik. Kualitas pelayanan seperti yang dirasakan oleh para konsumen, berasal dari suatu perbandingan antara apa yang ditawarkan oleh suatu perusahaan pelayanan yaitu harapan dan dengan persepsi mereka tentang kinerja pemberi jasa. Berdasarkan latar belakang tersebut, studi ini bertujuan untuk meningkatkan kepuasan pelanggan Hotel X di Semarang dengan menganalisis pengaruh lima dimensi kualitas jasa terhadap kepuasan pelanggan.

\section{B. TELAAH PUSTAKA}

\section{Kepuasan Pelanggan}

Menurut Kotler \& Keller (2012), "Satisfaction is a person's feelings of pleasure or dissapointment that result from comparing a product's perceived performance or outcome to expectations. If the performance falls short of expectations, the outcome is dissatisfied. If it matches expectations, the customer is satisfied or delighted". Hal ini berarti kepuasan adalah perasaan puas atau kecewa seseorang yang dihasilkan dari perbandingan performa produk atau hasil dengan ekspektasi. Jika performanya kurang dari ekspektasi maka konsumen akan kecewa dan jika sesuai dengan ekspektasi konsumen akan merasa puas diartikan sebagai upaya pemenuhan sesuatu atau membuat sesuatu memadai. Tjiptono dan Chandra (2011) menyatakan bahwa ada sejumlah metode untuk mengukur dan memantau kepuasan pelanggan diantaranya adalah 1) Complain and Suggestion System, 2) Ghost Shopping, 3) Lost Customer Analysis, dan 4) Customer Dissatisfaction.

\section{Kualitas Pelayanan}

Kualitas pelayanan adalah suatu bentuk penilaian konsumen terhadap tingkat pelayanan yang diterima dengan tingkat layanan yang diharapkan. Sedangkan menurut Tjiptono dan Chandra (2011), kualitas pelayanan adalah tolok ukur seberapa baik tingkat layanan yang diberikan dan mampu sesuai dengan harapan pelanggan. Menurut Parasuraman, et. al dalam Tjiptono dan Chandra (2011) kualitas pelayanan jasa memiliki lima dimensi pengukuran 
yaitu bukti fisik (tangibles), keandalan (realibility), daya tanggap (responsiveness), jaminan (assurance), dan empati (empathy).

\section{Hubungan Bukti Fisik (Tangibles) terhadap Kepuasan Pelanggan}

Bukti nyata kualitas pelayanan yang diberikan oleh perusahaan terlihat dari penampilan dan kemampuan sarana dan prasarana fisik perusahaan. Bukti fisik meliputi fasilitas, perlengkapan, pegawai hingga sarana komunikasi. Persepsi pelanggan dapat dipengaruhi oleh bukti fisik yang baik. Aspek ini juga merupakan salah satu sumber yang mempengaruhi harapan pelanggan. Dengan bukti fisik yang baik maka harapan pelanggan menjadi lebih tinggi, dapat memenuhi kebutuhan pelanggan dan memberikan kepuasan kepada pelanggan (Zeithaml, 2013). Lubis dan Andayani (2017), Suryadharma dan Nurcahya (2015) juga menyebutkan bahwa bukti fisik berpengaruh positif terhadap kepuasan pelanggan. Oleh karena itu hipotesis pertama yang dapat disusun adalah:

$\mathrm{H}_{1}$ : Bukti fisik (Tangibles) berpengaruh terhadap kepuasan pelanggan

\section{Hubungan Keandalan (Realibility) terhadap Kepuasan Pelanggan}

Keandalan (realibility) yaitu kemampuan perusahaan untuk melaksanakan jasa sesuai dengan apa yang telah dijanjikan dengan andal dan akurat. Kinerja harus sesuai dengan harapan pelanggan yang berarti ketepatan waktu, pelayanan yang sama untuk semua pelanggan tanpa kesalahan, sikap yang simpatik, dan dengan akurasi. Pentingnya dimensi ini adalah kepuasan konsumen akan menurun bila jasa yang diberikan tidak sesuai dengan yang dijanjikan. Semakin baik persepsi terhadap keandalan perusahaan maka kepuasan pelanggan akan semakin tinggi, selanjutnya jika persepsi terhadap keandalan buruk maka kepuasan pelanggan juga akan semakin rendah. Penelitian yang dilakukan oleh Apriyani dan Sunarti (2017), Panjaitan (2016) menyebutkan bahwa keandalan berpengaruh positif terhadap kepuasan pelanggan. Berdasarkan hal tersebut hipotesis kedua yang dapat disusun adalah:

$\mathrm{H}_{2}$ : Keandalan (realibility) berpengaruh terhadap kepuasan pelanggan

\section{Hubungan Daya Tanggap (Responsiveness) terhadap Kepuasan Pelanggan}

Daya tanggap (responsiveness) yaitu kemampuan perusahaan yang dilakukan langsung oleh karyawan untuk memberikan pelayanan dengan cepat dan tanggap. Daya tanggap dapat menumbuhkan persepsi yang positif terhadap kualitas jasa yang diberikan. Dimensi ini menekankan pada perhatian dan kecepatan karyawan yang terlibat untuk menanggapi permintaan, pertanyaan, dan keluhan pelanggan. Pelayanan yang tidak tanggap pasti akan membuat pelanggan merasa tidak puas. Daya tanggap yang diberikan oleh perusahaan dengan 
baik akan meningkatkan kepuasan yang dirasakan oleh pelanggan. Hasil penelitian yang dilakukan Sasongko dan Subagio (2013); Lubis dan Andayani (2017) menyebutkan bahwa daya tanggap berpengaruh positif terhadap kepuasan pelanggan. Oleh karena itu, hipotesis ketiga yang dapat disusun adalah:

$\mathrm{H}_{3}$ : Daya tanggap (responsiveness) berpengaruh terhadap kepuasan pelanggan

\section{Hubungan Jaminan (Assurance) terhadap Kepuasan Pelanggan}

Jaminan (assurance) adalah pengetahuan dan perilaku karyawan untuk membangun kepercayaan dan keyakinan pada diri pelanggan dalam mengkonsumsi jasa yang ditawarkan. Jika perusahaan menjamin keamanan pelanggan, maka pelanggan akan merasa aman dan tidak ada keraguan lagi untuk memakai produk/layanan perusahaan. Sebaliknya jika tidak ada jaminan keamanan, pelanggan akan merasa was-was. Keinginan pelanggan akan jaminan yang dapat dipenuhi oleh perusahaan dapat menimbulkan perasaan puas. Suryadharma dan Nurcahya (2015), Panjaitan (2016) menyebutkan bahwa jaminan berpengaruh positif terhadap kepuasan pelanggan. Berdasarkan hal tersebut hipotesis keempat yang dapat disusun adalah:

$\mathrm{H}_{4}$ : Jaminan (assurance) berpengaruh terhadap kepuasan pelanggan

\section{Hubungan Empati (Empathy) terhadap Kepuasan Pelanggan}

Kepekaan akan kebutuhan pelanggan, serta kemampuan untuk memberikan perhatian secara individu terhadap pelanggan merupakan bentuk dari empati. Pelanggan akan merasa puas jika diperhatikan oleh perusahaan, keluhan-keluhannya ditanggapi dan mendapatkan komunikasi dua arah yang baik dari perusahaan. Kepedulian atau empati mempunyai pengaruh positif terhadap kepuasan pelanggan. Semakin tinggi kepedulian yang diberikan oleh perusahaan maka kepuasan pelanggan juga akan semakin tinggi. Sasongko dan Subagio (2013), Lubis dan Andayani (2017) menyebutkan bahwa empati berpengaruh positif terhadap kepuasan pelanggan. Hipotesis kelima yang disusun dalam penelitian ini adalah:

$\mathrm{H}_{5}$ : Empati (empathy) berpengaruh terhadap kepuasan pelanggan 
Gambar 1. Kerangka Pemikiran

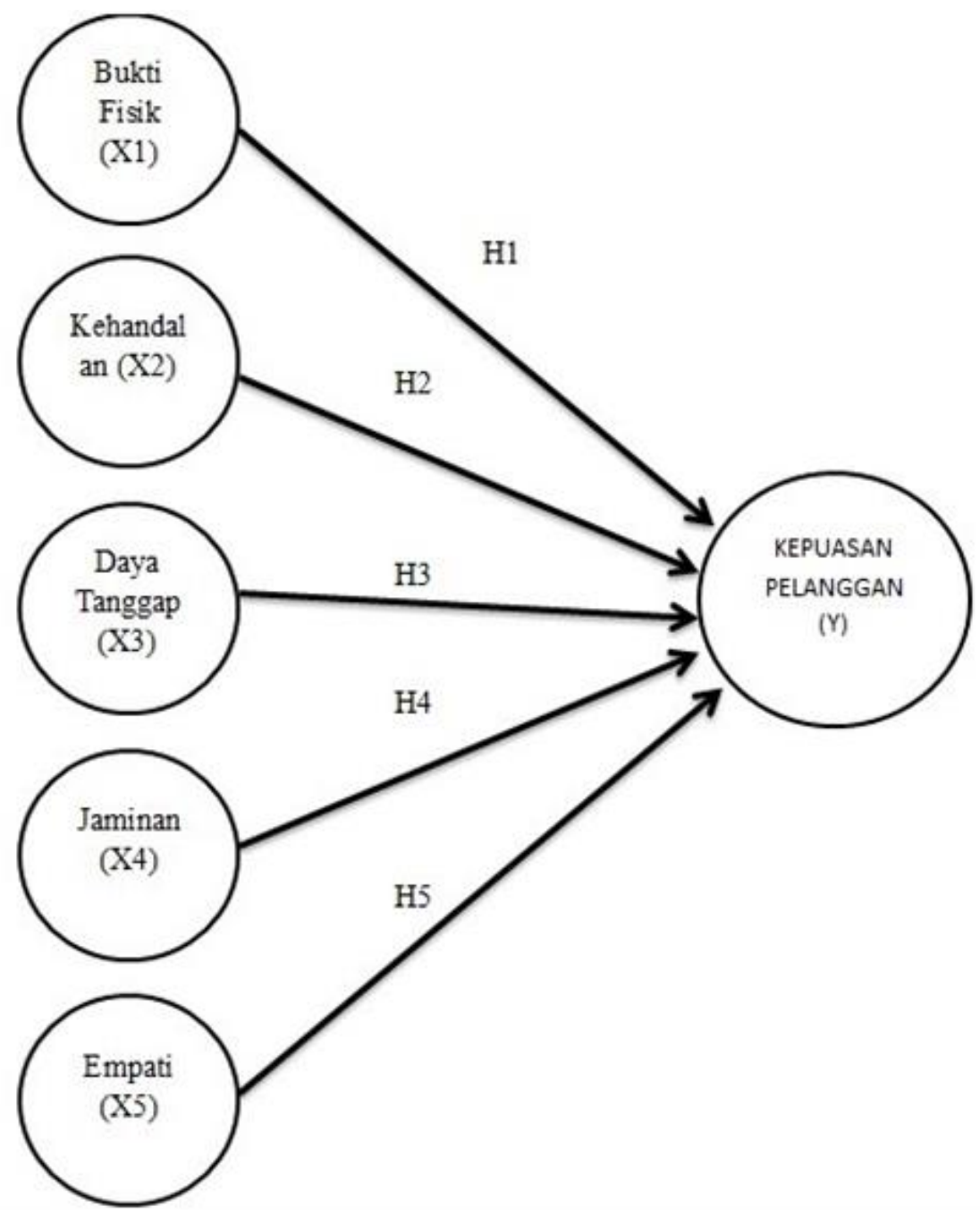

\section{METODE PENELITIAN}

Penelitian ini menggunakan pendekatan kuantitatif dengan analisis regresi berganda. Pengumpulan data dilakukan melalui penyebaran kuesioner. Penelitian dilaksanakan di Hotel X Semarang. Alasan peneliti memilih hotel tersebut sebagai lokasi penelitian karena di sana terdapat permasalahan yang akan dikaji atau diteliti yaitu tentang kepuasan pelanggan yang menurun yang dilihat dari kenaikan jumlah komplain pelanggan. Populasi dalam penelitian ini adalah pelanggan di Hotel X Semarang dengan jumlah yang tidak diketahui. Teknik sampling yang digunakan adalah teknik non probability sampling dengan jenis purposive sampling yang merupakan pemilihan anggota sampel yang didasarkan atas tujuan dan pertimbangan tertentu dari peneliti. Besar sampel dihitung dengan rumus sebagai berikut:

$$
n=\frac{Z^{2}}{4(M o e)^{2}}
$$


Keterangan :

n : Ukuran sampel

$\mathrm{Z} \quad$ : 1,96 skor pada tingkat signifikansi tertentu (95\%)

Moe : Tingkat kesalahan maksimum adalah 10\%

Dengan menggunkan rumus diatas, maka diperoleh perhitungan sebagai berikut:

$$
n=\frac{1,96^{2}}{4(10 \%)^{2}}=96.04 \text { dibulatkan menjadi } 96 \text { orang }
$$

\section{HASIL DAN PEMBAHASAN}

\section{Uji Instrumen dan Asumsi Klasik}

\section{Uji Validitas dan Reliabilitas Data}

Hasil uji validitas menunjukkan semua indikator dari dinyatakan valid dengan nilai $r$ hitung lebih besar dari $r$ tabel $(0,168)$. Selanjutnya hasil uji reliabilitas menunjukkan bahwa semua variabel mempunyai koefisien alpha yang cukup besar yaitu lebih besar dari 0,70 dengan demikian semua indikator hasilnya reliabel.

Tabel 2. Hasil Uji Validitas dan Reliabilitas

\begin{tabular}{|l|l|l|c|c|}
\hline No & \multicolumn{2}{|c|}{ Variabel } & r Hitung & Alpha \\
\hline 1 & Tangible $(X 1)$ & Indikator X1.1 & 0,852 & 0,837 \\
& & Indikator X1.2 & 0,846 & 0,851 \\
& & Indikator X1.3 & 0,839 & 0,842 \\
& & Indikator X1.4 & 0,879 & 0,823 \\
\hline 2 & Reliability (X2) & Indikator X2.1 & 0,883 & 0,722 \\
& & Indikator X2.2 & 0,861 & 0,722 \\
\hline 3 & Responsiveness (X3) & Indikator X3.1 & 0,875 & 0,751 \\
& & Indikator X3.2 & 0,886 & 0,751 \\
\hline 4 & Assurance (X4) & Indikator X4.1 & 0,907 & 0,769 \\
& & Indikator X4.2 & 0,777 & 0,850 \\
& & Indikator X4.3 & 0,784 & 0,847 \\
& & Indikator X4.4 & 0,884 & 0,802 \\
\hline 5 & Emphaty (X5) & Indikator X5.1 & 0,935 & 0,726 \\
& & Indikator X5.2 & 0,923 & 0,726 \\
\hline 6 & Kepuasan Pelanggan (Y) & Indikator Y.1 & 0,816 & 0,798 \\
& & Indikator Y.2 & 0,756 & 0,828 \\
& & Indikator Y.3 & 0,867 & 0,744 \\
& & Indikator Y.4 & 0,821 & 0,779 \\
\hline
\end{tabular}

Sumber: Data primer diolah 


\section{Uji Normalitas dan Multikolinieritas}

Hasil output dari pengujian normalitas dengan Kolomagorov-Smirnov menunjukkan nilai signifikansi sebesar 0.966 lebih besar dari 0,05 yang artinya bahwa nilai residual sudah terdistribusi normal. Pengujian multikolonieritas dilakukan dengan menggunakan nilai VIF. Nilai VIF dari variabel bebas pada model regresi menunjukkan bahwa variabel bebas memiliki nilai yang lebih kecil dari 10 (sepuluh) yang berarti antar variabel independen tidak terjadi korelasi dalam model regresi.

\section{Uji Heterokedastisitas}

Model regresi yang baik adalah tidak terjadi heteroskedastisitas, dimana dalam uji heteroskedastisitas ini menggunakan uji glejser. Hasil uji glejser menunjukkan bahwa semua variabel independen mempunyai nilai signifikansi lebih besar dari 0,05 hasil tersebut menunjukkan bahwa tidak terjadi ketidaksamaan variance dari pengamatan satu dengan pengamatan lainnya.

\section{Analisis Regresi Berganda dan Uji Hipotesis}

Analisis regresi berganda digunakan untuk menguji hipotesis yaitu tentang pengaruh variabel independen terhadap variabel dependen. Hasil pengujian memberikan nilai koefisien persamaan regresi yang menunjukkan besarnya pengaruh variabel independen terhadap variabel dependen dan signifikansi pengaruh tersebut.

Tabel 3. Hasil Uji Regresi Linear Berganda dan Hipotesis

\begin{tabular}{|l|c|c|c|c|c|}
\hline \multicolumn{1}{|c|}{ Model } & $\begin{array}{c}\text { Standardized } \\
\text { Coefficients } \\
\text { Beta }\end{array}$ & T & Sig & Tolerance & VIF \\
\hline Tangible $\left(\mathrm{X}_{1)}\right.$ & 0,255 & 3,100 & 0,003 & 0,687 & 1,456 \\
\hline Reliability $\left(\mathrm{X}_{2}\right)$ & 0,314 & 4,073 & 0,000 & 0,779 & 1,284 \\
\hline Responsiveness $\left(\mathrm{X}_{3}\right)$ & 0,172 & 2,329 & 0,022 & 0,850 & 1,177 \\
\hline Assurance $\left(\mathrm{X}_{4}\right)$ & 0,275 & 3,863 & 0,000 & 0,917 & 1,091 \\
\hline Empathy $\left(\mathrm{X}_{5}\right)$ & 0,301 & 4,265 & 0,000 & 0,934 & 1,071 \\
\hline
\end{tabular}

a. Dependent Variable: Kepuasan Pelanggan

Sumber: Data primer diolah

Persamaan regresi dari hasil uji regresi linear berganda adalah sebagai berikut:

$$
\mathrm{Y}=0,255 \mathrm{X}_{1}+0,314 \mathrm{X}_{2}+0,172 \mathrm{X}_{3}+0,275 \mathrm{X}_{4}+0,301 \mathrm{X}_{5}
$$

Tabel 3 menunjukkan bahwa variabel independen yang memiliki pengaruh terbesar terhadap kepuasan pelanggan yaitu reliability, dengan nilai koefisien regresi sebesar 0,314. Dari tabel tersebut juga menunjukkan bahwa seluruh variabel independent memiliki pengaruh positif signifikan terhadap kepuasan pelanggan. 
Selanjutnya pengujian koefisien determinasi $\left(\mathrm{R}^{2}\right)$ bertujuan mengukur besarnya kemampuan model persamaan regresi (independen variables) dalam menerangkan variabel terikat. Tabel 4 menunjukkan bahwa nilai adjusted $R$ square pada model regresi diperoleh sebesar 0,559 yang artinya 55,9\% variasi variabel kepuasan pelanggan dapat dijelaskan oleh variabel tangible, realibility, responsiveness, assurance dan empathy.

Tabel 4. Hasil Uji Koefisien Determinasi

\begin{tabular}{|c|c|c|c|c|}
\hline Model & R & R Square & $\begin{array}{c}\text { Adjusted } \\
\text { R Square }\end{array}$ & $\begin{array}{c}\text { Std. Error of } \\
\text { the Estimate }\end{array}$ \\
\hline 1 & 0,763 & 0,582 & 0,559 & 1,58887 \\
\hline
\end{tabular}

Sumber: Data primer diolah

\section{Pembahasan}

Hasil regresi berganda menunjukkan bahwa reliabilitas (keandalan) memiliki pengaruh yang paling besar terhadap kepuasan pelanggan Hotel X di Semarang. Reliabilitas diartikan sebagai kemampuan perusahaan untuk melaksanakan jasa sesuai dengan apa yang telah dijanjikan dengan andal dan akurat (Tjiptono, 2012). Seseorang yang akan menginap di hotel akan membawa harapan akan pelayanan hotel tersebut. Harapan-harapan yang dibawa konsumen berasal dari informasi yang mereka dapatkan. Dalam hal ini terkait dengan pelayanan hotel, sebelum menginap di hotel yang dituju seseorang memiliki kecenderungan mencari informasi terkait dengan pelayanan hotel tersebut. Misalnya saat memilih Hotel X di Semarang yang merupakan hotel bintang 2, konsumen akan mengumpulkan informasi terkait pelayanan hotel bintang 2 tersebut. Informasi tersebut membentuk harapan konsumen bahwa jika mereka menginap di Hotel X mereka akan mendapatkan pelayanan sesuai dengan apa yang diinformasikan. Hal inilah terlihat bagaimana reliabilitas (keandalan) dari sebuah hotel berpengaruh besar terhadap kepuasan pelanggan. Kesesuaian harapan konsumen yang berasal dari informasi yang dia dapatkan dengan kemampuan hotel dalam memenuhi pelayanan sesuai yang mereka informasikan atau janjikan.

Tjiptono (2012) menyatakan bukti fisik (tangibles) merupakan suatu pelayanan yang bisa dilihat, bisa dicium dan bisa diraba, maka aspek tangible menjadi penting sebagai ukuran terhadap pelayanan. Penampilan dan kemampuan sarana dan prasarana fisik perusahaan dan keadaan lingkungan sekitarnya adalah bukti nyata dari pelayanan yang diberikan oleh pemberi jasa. Hal ini meliputi fasilitas fisik perlengkapan, pegawai, dan sarana komunikasi. Hasil penelitian yang sudah dilakukan menunjukkan bahwa tangible merupakan salah satu 
faktor yang mempengaruhi kepuasan pelanggan. Apabila Hotel X di Semarang ingin meningkatkan tangible, maka hotel tersebut harus lebih memperhatikan indikator kebersihan hotel, fasilitas fisik, perlengkapan salah satu faktor yang mempengaruhi kepuasan pelanggan. Hasil penelitian ini mendukung hasil penelitian dari Suryadharma dan Nurcahya (2015) dan Lubis dan Andayani (2017) yang menyatakan tangible berpengaruh positif dan signifikan terhadap kepuasan pelanggan.

Pentingnya keandalan atau reliability ini adalah kepuasan konsumen akan menurun bila jasa yang diberikan tidak sesuai dengan yang dijanjikan. Jadi komponen atau unsur dimensi reliability ini meliputi ketepatan waktu dan kecakapan dalam menanggapi keluhan pelanggan serta pemberian pelayanan secara wajar dan akurat. Hasil penelitian yang sudah dilakukan mendapatkan bahwa realibility berpengaruh secara positif dan signifikan terhadap kepuasan pelanggan. Apabila Hotel X Semarang ingin meningkatkan realibility, maka harus lebih memperhatikan indikator prosedur pelayanan yang andal dan ketepatan pemenuhan janji. Hasil penelitian ini mendukung hasil penelitian dari Apriyani dan Sunarti (2017) dan Panjaitan (2016) yang menyatakan realibility berpengaruh positif dan signifikan terhadap kepuasan pelanggan.

Tjiptono (2012) menyatakan daya tanggap (responsiveness) merupakan kemampuan perusahaan yang dilakukan langsung oleh karyawan untuk memberikan pelayanan dengan cepat dan tanggap. Jadi komponen atau unsur dari dimensi ini terdiri dari kesigapan karyawan dalam melayani pelanggan, kecepatan karyawan dalam melayani pelanggan dan penanganan keluhan pelanggan. Hasil penelitian menunjukkan bahwa responsiveness merupakan salah satu faktor yang mempengaruhi kepuasan pelanggan, responsiveness berpengaruh secara positif dan signifikan terhadap kepuasan pelanggan. Apabila Hotel X Semarang ingin meningkatkan responsiveness, maka harus lebih memperhatikan indikator cepat tanggap dalam menghadapi masalah dan cepat tanggap terhadap keluhan yang disampaikan. Hasil penelitian ini mendukung hasil penelitian dari Sasongko dan Subagio (2013) dan Lubis dan Andayani (2017) yang menyatakan responsiveness berpengaruh positif dan signifikan terhadap kepuasan pelanggan.

Komponen dari jaminan (assurance) terdiri dari kompetensi karyawan yang meliputi keterampilan, dan pengetahuan yang dimiliki karyawan untuk melakukan pelayanan. Komponen lain dari dimensi ini adalah kredibilitas perusahaan yang meliputi hal-hal yang berhubungan dengan kepercayaan pelanggan kepada perusahaan seperti, reputasi perusahaan, prestasi, dan lain-lain. Hasil penelitian yang sudah dilakukan menunjukkan bahwa assurance 
merupakan salah satu faktor yang mempengaruhi kepuasan pelanggan. Assurance berpengaruh secara positif dan signifikan terhadap kepuasan pelanggan. Apabila Hotel X Semarang ingin meningkatkan assurance, maka harus lebih memperhatikan indikator pengetahuan karyawan, kemampuan karyawan, kesopanan karyawan dan sifat dapat dipercaya yang dimiliki karyawan. Hasil penelitian ini mendukung hasil penelitian dari Suryadharma dan Nurcahya (2015) dan Panjaitan (2016) yang menyatakan assurance berpengaruh positif dan signifikan terhadap kepuasan pelanggan.

Tjiptono (2012) menyatakan empati (empathy) merupakan kemampuan perusahaan yang dilakukan langsung oleh karyawan untuk memberikan perhatian kepada pelanggan secara individu, termasuk juga kepekaan atau kebutuhan pelanggan. Komponen dari dimensi ini merupakan gabungan dari akses (access) yaitu kemudahan untuk memanfaatkan jasa yang ditawarkan oleh perusahaan. Hasil penelitian yang sudah dilakukan menunjukkan bahwa empathy merupakan salah satu faktor yang mempengaruhi kepuasan pelanggan. Hasil penelitian yang sudah dilakukan mendapatkan bahwa empathy berpengaruh secara positif dan signifikan terhadap kepuasan pelanggan. Apabila Hotel X Semarang ingin meningkatkan empathy, maka harus lebih memperhatikan indikator perhatian karyawan dan pelayanan pribadi yang diberikan kepada pelanggan. Hasil penelitian ini mendukung hasil penelitian dari Sasongko dan Subagio (2013) dan Lubis dan Andayani (2017) yang menyatakan empathy berpengaruh positif dan signifikan terhadap kepuasan pelanggan.

\section{E. KESIMPULAN}

Hasil penelitian menunjukkan bahwa bukti fisik (tangibles) berpengaruh positif dan signifikan terhadap kepuasan pelanggan. Hal ini berarti apabila bukti fisik (tangibles) ditingkatkan maka akan meningkatkan kepuasan pelanggan. Selain itu, keandalan (reliability) berpengaruh positif dan signifikan terhadap kepuasan pelanggan. Hal ini berarti apabila keandalan (reliability) ditingkatkan maka akan meningkatkan kepuasan pelanggan. Selanjutnya, daya tanggap (responsiveness) berpengaruh positif dan signifikan terhadap kepuasan pelanggan. Dengan demikian apabila daya tanggap (responsiveness) ditingkatkan maka akan meningkatkan kepuasan pelanggan. Variabel jaminan (assurance) berpengaruh positif dan signifikan terhadap kepuasan pelanggan. Oleh karena itu, apabila jaminan (assurance) ditingkatkan maka akan meningkatkan kepuasan pelanggan. Hasil lain yang ditunjukkan yaitu empati (empathy) berpengaruh positif dan signifikan terhadap kepuasan 
pelanggan. Dengan demikian, apabila empati (empathy) ditingkatkan maka akan meningkatkan kepuasan pelanggan.

\section{Saran}

Berdasarkan alat uji analisis diskriptif diketahui masih ada beberapa indikator yang memiliki skor rendah dibandingkan indikator lainnya. Hal tersebut mencerminkan bahwa masih banyak yang harus ditingkatkan dalam meningkatkan kepuasan pelanggan Hotel X Semarang. Untuk itu saran yang dapat diberikan antara lain yang untuk meningkatkan variabel bukti fisik (tangibles) pada indikator fasilitas fisik yang memiliki skor terendah dibandingkan indikator yang lainnya. Hal ini dapat dilakukan dengan cara Hotel X Semarang menambahkan beberapa fasilitas seperti tempat fitness, kolam renang dan lain-lain agar menciptakan kepuasan pelanggan yang lebih. Saran lainnya adalah untuk meningkatkan variabel keandalan (reliability) pada indikator prosedur pelayanan. Disarankan agar Hotel X Semarang memberikan kejelasan SOP dengan cara menempelkan brosur yang membuat pelanggan memahami prosedur yang ada di Hotel X Semarang.

Saran selanjutnya adalah untuk meningkatkan variabel daya tanggap (responsiveness) pada indikator cepat tanggap dalam menghadapi masalah memiliki skor terendah dibandingkan indikator yang lainnya. Disarankan agar Hotel X Semarang memberikan layanan call center supaya mempermudah pelanggan dan hotel dalam menyelesaikan masalah yang timbul. Selain itu untuk meningkatkan variabel jaminan (assurance) pada indikator pengetahuan karyawan memiliki skor terendah dibandingkan indikator yang lainnya disarankan agar Hotel X Semarang memberikan pelatihan dan motivasi kepada karyawan agar memiliki pengetahuan yang baik ketika bekerja. Saran lainnya adalah untuk meningkatkan variabel empati (empathy) pada indikator perhatian karyawan memiliki skor terendah dibandingkan indikator yang lainnya. Hal ini dapat dilakukan Hotel X Semarang dengan memberikan logo atau emblem yang menempel di seragam karyawan agar membuat karyawan lebih memperhatikan sikap perhatian karyawan kepada pelanggan. Serta saran selanjutnya adalah agar Hotel X Semarang dapat meningkatkan pelayanan yang sesuai dengan apa yang dijanjikan kepada pelanggan.

\section{DAFTAR PUSTAKA}

Ahmed, L., et al. (2010). A Mediation of Customer Saticfaction Relationship Between Service Quality and Repurchase Intentions for The Telecom Sector in Pakistan: A Case study of University students, African Journal of Business Management, 4(16), 3457-3462 
Andayani, A. S. (2017). Pengaruh Kualitas Pelayanan (Service Quality) Terhadap Kepuasan Pelanggan PT Sucofindo Batam. Journal of Business Administration, 1(2), 86-97.

Apriyani, D. A., \& Sunarti, S., (2017). Pengaruh Kualitas Pelayanan Terhadap Kepuasan Konsumen . Jurnal Administrasi Bisnis (JAB), 51(2). 1-7

Gocek, I., Kursun, S., \& Beceren, Y. I. (2007). The Perception of Customer Satisfaction in Textile Industry According To Genders in Turkey. International Journal of Human and Social Sciences, 1(2). 193-196

Hasan, Ali. (2009). Marketing. Jakarta: Media Presindo.

Kotler, Philip., \& Keller, K. L. (2012). Marketing Management, (Ed. 14). NewJersey: Prentince Hall.

Laziami, Irta. (2015). Faktor-Faktor Yang Mempengaruhi Kepuasan Konsumen Dalam Membeli Tiket Pada PT Riau Karsa Pelita Kota Pekanbaru. Jurusan Ilmu Administrasi, Program Studi Pariwisata, Fakultas Ilmu Sosial Dan Ilmu Politik, Universitas Riau.

Lubis, A. S., \& Andayani, N. R. (2017). Pengaruh Kualitas Pelayanan (Service Quality) Terhadap Kepuasan Pelanggan PT Sucofindo Batam. Journal of Business Administration, 1(2), 86-97.

Panjaitan, J. E. (2016). Pengaruh Kualitas Pelayanan Terhadap Kepuasan Pelanggan JNE Bandung. DeReMa Jurnal Manajemen, 11(2), 265-289.

Sasongko, F., \& Subagio, H. (2013). Pengaruh Kualitas Layanan Terhadap Kepuasan Pelanggan Restoran Ayam Penyet Ria. Jurnal Manajemen Pemasaran Petra, 1(2).

Sunarti, A. (2017). Pengaruh Kualitas Pelayanan Terhadap Kepuasan Konsumen (Survei pada Konsumen The Little A Coffee Shop Sidoarjo). Jurnal Administrasi Bisnis (JAB), 51(2), 1-7.

Sulastiyono, A. (2011). Manajemen Penyelenggaraan Hotel: Manajemen Hotel. Bandung: Alfabeta.

Suryadharma, I W. W., \& Nurcahya, I K. (2015). Pengaruh Kualitas Pelayanan Pada Kepuasan Pelanggan Hotel Bintang Pesona. E-Jurnal Manajemen Unud, 4(4), 930942. 1-7

Tjiptono, F., \& Gregorius, C. (2011). Service, Quality, \& Satisfaction, (Ed.3). Yogyakarta: ANDI.0

Tjiptono, F. (2012). Strategi Pemasaran, (Ed. 3). Yogyakarta: ANDI.

Zeithaml, V.A, Bitner, M.J, \& Gremler D.D. (2013). Service Marketing: Integrating Customer Focus Across the Firm, (Ed.6). New York: McGraw-Hill Companies, Inc. 